\title{
New England
}

Emerging Issues in Community Development and Consumer Affairs

\section{What Do the Neighbors Think? Assessing the Community Impact of Neighborhood Stabilization Efforts}

\section{By Erin M. Graves, Federal Reserve Bank of Boston}

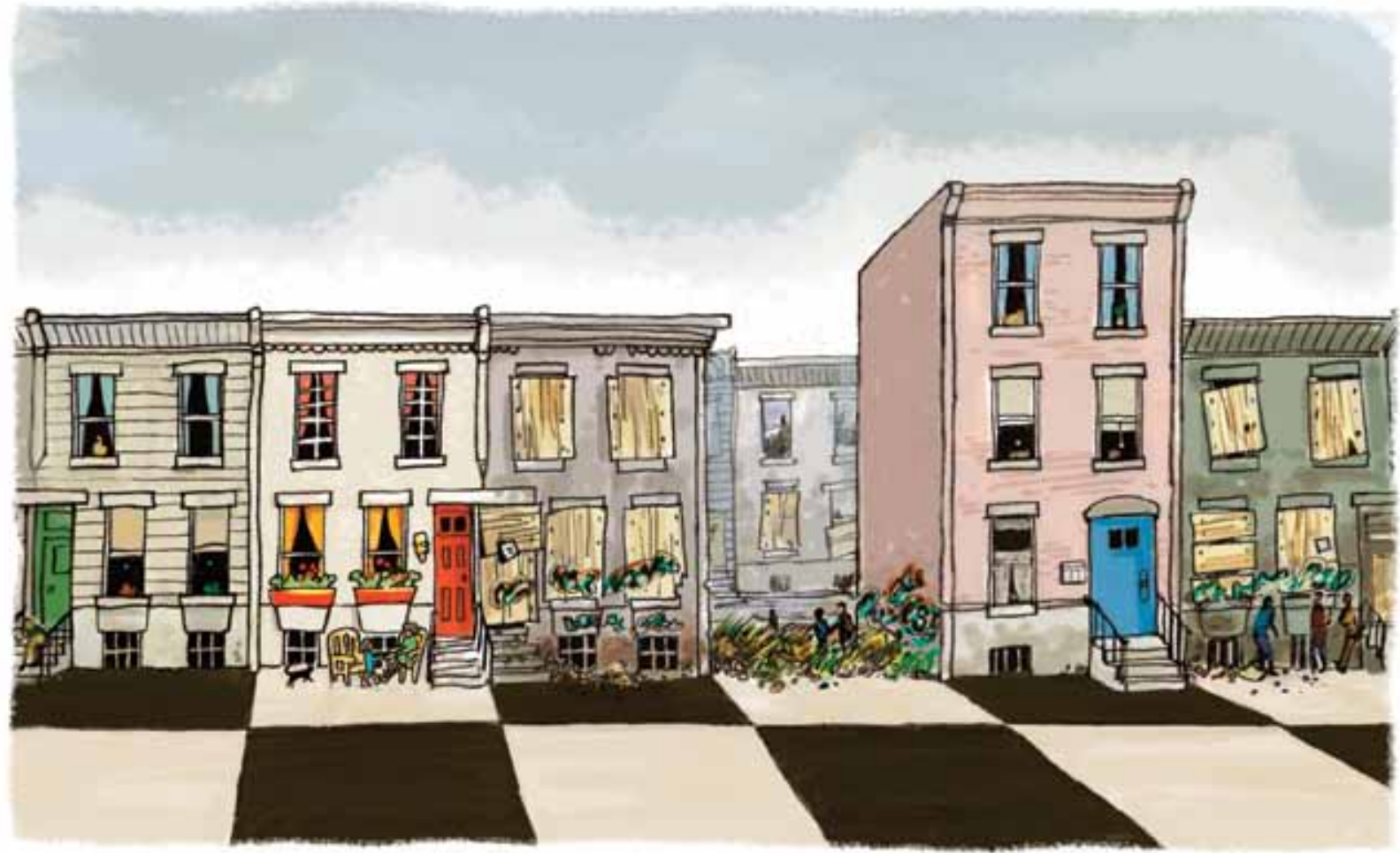

As a qualitative researcher, I believe that essential to understanding the socioeconomic conditions of the population I am studying is to experience those conditions for myself. The ideal experience would be to become part of the population through years of immersion, which is not often practical professionally or personally. Still, when I began trying to assess the impact of a foreclosure intervention policy on Boston's high-foreclosure neighborhoods, which are also its poorest, most crime-filled and racially segregated, I knew I needed to be there, if not day and night, at least day after day.

The federally funded Neighborhood Stabilization Program (NSP) gave the City of Boston several million dollars to acquire, rehabilitate, and resell abandoned, foreclosed homes in high-foreclosure neighborhoods. The federal government required grantees to acquire foreclosed properties within "areas of greatest need" (which HUD also refers to as "target areas"). The low-income 
neighborhoods of Dorchester and Roxbury fulfilled these criteria with less than a fifth of all housing units, but nearly 50 percent of the foreclosures. ${ }^{1}$ These two neighborhoods also had disproportionate crime rates: in 2009, 17 of the 33 homicides from firearms in Boston occurred in Dorchester and Roxbury, despite the fact that just $1 / 5$ of the population lived there. ${ }^{2}$ Similarly, 35 percent of the violent crimes and 24 percent of the property crimes occurred in these two neighborhoods. ${ }^{3}$

The NSP sought to limit what Mallach calls "secondary effects of the mortgage crisisthe economic and social impacts on properties, neighborhoods and communities." Mallach suggests that these will actually affect people more strongly than foreclosure itself. ${ }^{4}$ Attempts to quantify the impacts, such as the changes to property values of nearby homes, are underway. For example, HUD engaged Abt Associates to conduct a large-scale study to be completed in 2014. However, I know of no attempts to assess the impact of the program based on residents' perspectives on neighborhoodlevel social capital and social disorder, which are indications of neighborhood social stability. My question was whether the policy would have an impact on neighborhood social stability. Neighborhood social stability matters in part because it is linked to price stability: high residential turnover coupled with neighborhood distress lowers home prices. ${ }^{5}$ To reach residents and learn about the level of social stability, I decided to go door-to-door in the target areas and administer the standardized and validated "Sense of Community" survey, which assesses residents' perceptions of social capital and social disorder. I targeted both the group of homes receiving the NSP intervention and a control group of abandoned foreclosed homes in the neighborhood. I augmented the survey with two open-ended qualitative questions. ${ }^{6}$ In addition to the eight properties acquired with NSP funds, I identified eight more abandoned, foreclosed properties in the neighborhoods, which serve as the control group. I intend to administer this survey longitudinally; the first round prior to the intervention and the second round after the intervention is completed. This method will allow me to assess changes in residents' perceptions of social stability. Therefore I am presenting preliminary findings reflecting themes from the first round of surveys and a discussion of how these themes might relate to policy formation.
Believing that the rehabilitation intervention would have the greatest impact on those who live closest to an abandoned building my research colleague and I included all residents of buildings directly abutting, one house away, and directly across the street. Figure 1 below illustrates a typical block and the houses that would have been considered. Exceptions were made, for example, when upon

\section{Figure 1: Typical Study Neighborhood}

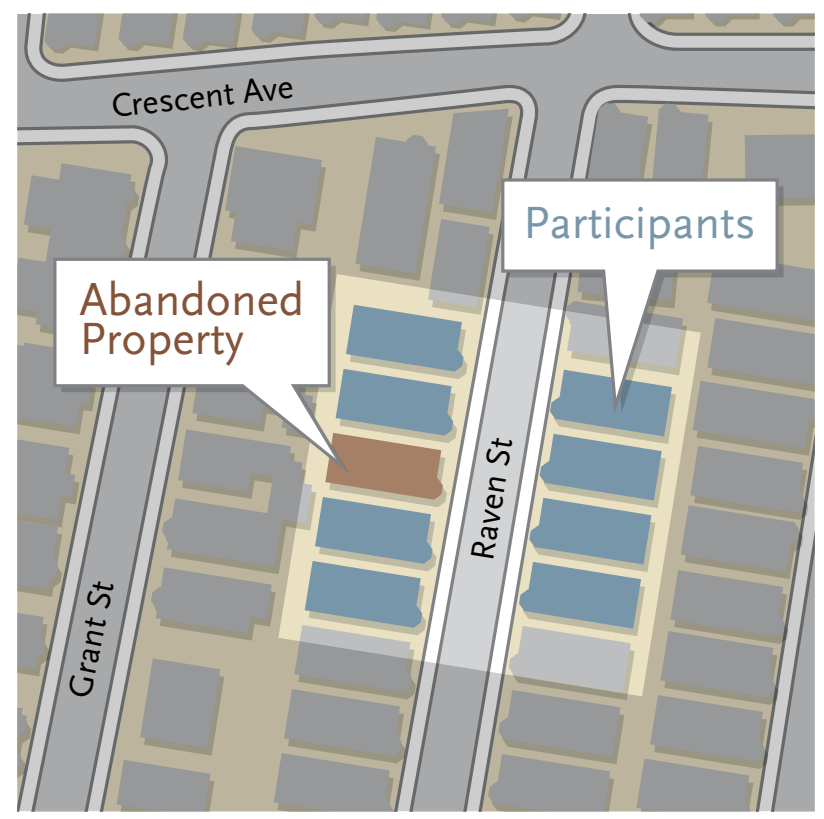

Source: Federal Reserve Bank of Boston

visiting the block we noted that a house outside the above criteria had a very clear view of the abandoned house. The first set of properties we considered our "treatment" population and the second set we considered the "control" population. The number of buildings in our survey totaled 141, and these buildings were almost exclusively 2 and 3 unit buildings, for a total of 275 households.

We attempted to conduct an in-person interview at every unit in our universe. Based on a resident list maintained by the City of Boston, we estimated 538 qualifying adults living in the 275 households. We rang the doorbell or knocked. If someone answered, we introduced ourselves and explained the survey. We administered the survey to willing residents over 18 in the entryway or in some instances inside the respondent's home. We compensated all participants with a money order for $\$ 20$. For the few residents who were not interested, we removed the unit from our list. If no one answered the door, we left a flyer with our phone number. We visited neighborhoods 
and conducted surveys between the hours of $2 \mathrm{pm}$ and $8 \mathrm{pm}$ on weekdays and Sundays in June and July 2011. We administered 58 surveys, reaching about 10 percent of qualified adults and about 20 percent of our target households. We also assessed the physical condition of all 141 parcels using a parcel condition worksheet.

I based the parcel condition worksheet on the Project on Human Development in Chicago Neighborhoods. Though the worksheet anticipated that we would observe "groups of people hanging out," "drug use," and "drug dealing" on our target blocks, we soon realized that none of these were frequent enough to make our parcel condition survey meaningful. The signs of distress were more subtle -poorly maintained lawns or debris on porches. So despite being among Boston's worst areas in terms of crime and foreclosures, these neighborhoods seemed rather ordinary during our daytime visits. In addition to visiting the 16 blocks we targeted, we spent time in restaurants and stores. Though patrons and employees sometimes offered us hospitality, we were most often treated with indifference and occasionally suspicion. One day, I remarked to my co-researcher that though we had passed a large and oftencrowded city park with a new-looking and colorful playground a number of times, I had never before noted its name - Harambee Park. However, several days later, many people would hear of Harambee Park, where a 4-year-old boy was shot while on the playground by a gang of young men. I relate this episode to suggest what living on these target blocks might feel like - most of the time neighborhood life is rather prosaic, but is occasionally punctuated by alarming anti-social behavior that too frequently concludes tragically.

When residents either did not answer their doors or were not home, we attempted to contact them through a mailing. ${ }^{7}$ Using both the in-person and mail-in outreach methods, we interviewed or surveyed 148 residents from 263 households. Of those, 82 contained qualitative responses (58 in-person interviews and 24 write-in responses). All but two participants were people of color, most selfidentified as "Black/African American," but others identified as Trinidadian, Jamaican, or Haitian. Additional residents classified themselves as Latino, Hispanic, Puerto Rican, or Dominican.

\section{Preliminary Findings}

While our full results will not be available until late 2012, after our second round of surveys following NSP intervention, a number of interesting trends among qualitative and policy-related responses are worth relating now. I analyzed the qualitative responses using the software NVivo, which allows coding themes. I developed an initial set of themes based on the two qualitative questions: general impression of the neighborhood and factors they believed influenced home price. Additional themes included aligning demographic groups (e.g., similarities in perspectives of homeowners versus renters or women versus men).

One observation was immediately obvious. While we intended to talk to residents about abandoned, foreclosed homes, the topic that most interested them was neighborhood stability, especially crime in general and gun violence in particular.

\section{“Wow, it's a foreclosure. Nobody knows}

\section{about it." — Male Renter}

The residents who did answer their doors often welcomed us, unsolicited, into their homes, where we would listen to their responses. Three interrelated themes appeared in those interviews and mail-in written responses. First, residents did not view the abutting abandoned, foreclosed home as a primary threat to neighborhood stability. Second, residents expressed a strong belief in the power of but their alienation from public and private institutions such as city government and banks. The third theme centers on how residents of unstable neighborhoods define social and spatial boundaries to make themselves feel secure. After examining these three themes, I will explain how they might influence policy formation.

\section{Resident Views of Abandoned, Foreclosed Homes}

The target areas were neighborhoods with many abandoned homes ${ }^{8}$, some on the same street as the foreclosed properties in question. Moreover, the neighborhoods contained many additional vacant parcels. Thus, with so many distressed properties in the neighborhood, it may not be that surprising that many residents did not know the home had been foreclosed on. As one male renter commented, "Wow, it's a foreclosure. Nobody knows about it."

For those who did know of the foreclosure, several explained it as an outcome of an individual 
problem rather than a sign of a community issue. Though some explanations included real estate deals gone bad and "swindling" by banks, speculation did not include how these individual problems might relate to larger neighborhood issues such as house prices or crime. Some residents did recall negative activity in the foreclosed home such as trespassing and large amounts of trash, and their response to it, including calling the police, city inspectors, and

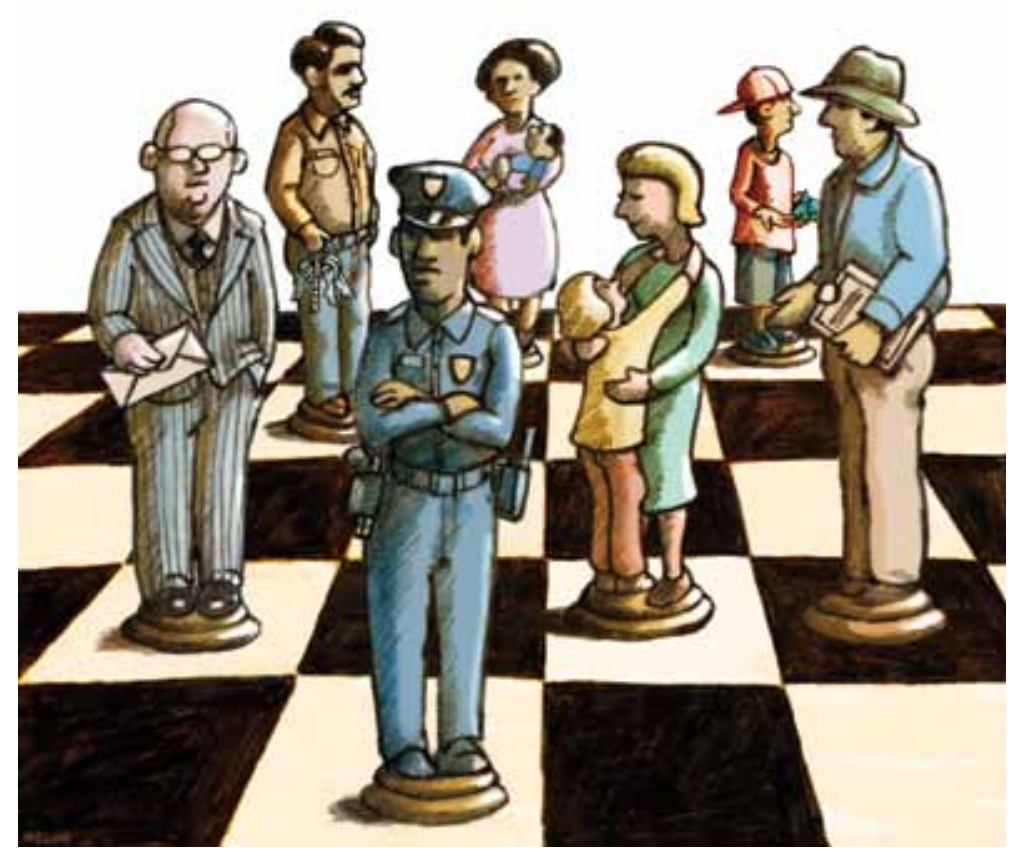

City Hall. One middle aged female renter told us that one day she saw several children come running out of the foreclosed home. She called the police and a neighborhood group. Soon thereafter, "They came and boarded it up." She had not observed any activity at the property after that event.

Additionally, contrary to accounts in the popular press, we rarely heard reports of crime in foreclosed homes. Most residents did not express concern that the properties were a target or magnet for crime. One possibility is that measures to secure abandoned homes, such as boarding them up, sufficiently dissuade trespassing. As noted before, these neighborhoods have many abandoned homes. Thus while an abandoned home may create an opportunity for illicit activity, with 99 abandoned homes littering the high foreclosure neighborhood landscape, there are possibly more opportunities than there are opportunists. However, even when foreclosed homes were not secured, our respondents did not offer many reports of trespassing on these premises.

Many residents made a connection between abandoned, foreclosed homes and vacant lots on the same block, suggesting that they viewed abandoned lots as an equal, if not greater, threat to neighborhood stability. For example, one middle aged female renter referenced the vacant lot next door to her (the foreclosed home abutted her on the other side). She commented of that vacant lot, "there goes your sense of community." Resident concerns included the accumulation of trash and the lack of intervention from the City of Boston, which several thought could improve the neighborhood.

\section{Other Threats to Neighborhood Stability}

While foreclosed homes did not generate much commentary, other neighborhood problems, especially crime and antisocial activity, did. Residents expressed concerns regarding assaults, drug dealing and addiction, home and auto break-ins, prostitution, and gang activity in their neighborhoods, though not in relation to the foreclosed homes. Moreover, while residents referenced a variety of criminal and antisocial activity, many also recalled specific incidents of gun violence. Different residents would frequently recall the same instance of gun violence on or near their block. Residents on nearly half of the blocks we visited (seven of 16) related some episode of gun violence, ranging from learning about a shooting, to hearing shots, seeing people lying in the street after being shot, to actually having bullets penetrate their apartment walls. As one female homeowner recounted, "Believe it or not, I have literally witnessed three people lying in the street after being shot. I don't know if you'll recall in the news, Halloween they shot someone. Another holiday they shot, it was a teenage boy." ${ }^{10}$ The fact that many residents from many target blocks had witnessed gun violence near their homes may explain why they did not see foreclosed homes as a salient threat to the neighborhood. Compared to an abandoned home, especially a securely boarded up one where little observable criminal activity took place, gun violence poses a much greater neighborhood threat.

\section{The Role of City and Community Institutions in Neighborhood Stability}

While crime and disorder may be seen as communitylevel problems, many believe these issues require a municipal response from police and city services. Respondents made comments regarding the performance of police and other institutional actors charged with maintaining social stability. First, 
many expressed confidence in the legitimacy and competence of the police and city officials but stated that their area is underserved. One young adult male renter noted that, "I feel like my neighborhood could be better if there was more cops in it." 11 Others complained about the performance of the police. However, no one argued that the police were not competent or trustworthy, which suggests that the institution is still legitimate in residents' eyes.

Additionally, many view local community organizations as effective in confronting some neighborhood problems and in communicating community concerns to city-level actors. Residents reported participating in a variety of activities including meetings, neighborhood watches, marches, vigils, email list serves, and neighborhood clean-ups, often organized through their place of worship. Other residents expressed the belief that neighborhood participation is necessary to bring about positive change and that people should become more involved. Many residents see building connections between local and municipal organizations as crucial in promoting neighborhood stability. One female homeowner "belongs to the neighborhood association which has monthly meetings and get a lot done, for example, they got stop signs. There is a community officer who reports to the group on the monthly crimes. Encourages everyone to call 911 if they see anything." Both homeowners and renters tended to report successful collaborations between local organizations and the police in maintaining social stability, citing examples dealing with crime, intimidation, and even late-night noise.

Nevertheless, some residents did express a sense of institutional abandonment and alienation. A few communicated their frustration with government services, beyond the city's inability to maintain abandoned lots, as discussed above. One young woman believed that her community's inability to effectively confront instability was "because the state's an ass." However, banks were one institution for which residents expressed an almost uniform lack of confidence and sometimes outright disdain. Residents often criticized connections between banks and government regarding foreclosures. Others placed the blame for foreclosures squarely on banks, mirroring general public frustration. For example, one resident complained, "I wish banks and other lenders could work with owners to avoid these problems."

\section{Stability and Sense of Community}

It may not come as a surprise that residents spoke of their neighborhoods in positive terms nearly as often as they expressed negative views. Sometimes the negative and positive perspective would be contained in the same sentiment. For example, a young male resident noted, "I love the neighborhood with the exception of prevalent drug dealing and prostitution that occurs around the corner."12 In reviewing survey responses, it became clear that many residents draw careful distinctions between well-intentioned insiders and poorly behaved outsiders. Such comments follow a pattern in which residents define safe areas as those inside their block, which they see populated by well-meaning neighbors. They contrast this to areas outside the block as populated by dangerous and threatening outsiders. Another resident vouched for her side of the street commenting, "We haven't had any trouble, as you say, where we can see. The other side is a different story." Another female renter phrased it more directly, "I find that lots of things happening in the area are done by outsiders."

It occurred to us that the distinctions might actually be coded language for racial and ethnic differences. These neighborhoods once housed mainly African Americans, but the demographics are now shifting to include Haitians, Jamaicans, Trinidadians, Somalians, Puerto Ricans, and Dominicans. However, in reviewing the racial

\section{"I wish banks and other lenders could work with owners to avoid these problems." — Resident}

and ethnic identity and owner/tenant status of the respondents who made distinctions between insiders and outsiders, no clear pattern emerges.

Residents also made distinctions about insiders and outsiders according to housing tenure, classifying homeowners as insiders who maintained stability and renters as outsiders who threatened it. Homeowners and renters both described homeowners as committed, responsible, and admirable community members and compare them favorably to renters, whom they tend to view as temporary and more likely to engage in disruptive or even criminal behavior. For example, an older male renter maintained a positive view of his block explaining, "there's homeowners and they seem to keep it up.” 
However, respondents did not always assume that long-term residents are homeowners. Residents repeatedly referred to long-term residents as a source of stability without directly referencing their ownership status. Respondents sometimes attributed neighborhood stability to residents' longterm presence.

\section{We visited many homes that contained three} generations of the same family. These residents expressed a heightened sense of responsibility for maintaining not only neighborhood stability but also the well-being of their family members.

Respondents did, however, make class distinctions based on income, at least where subsidized housing was concerned. As one older male renter explained, "And I don't like to generalize and category people, but the closer you get to the public housing, and to the, yeah, the closer you get to the end with public housing it's always a problem at that end. Where the private homes are you never see any police come down here, never any fights any argument, you know none of that outlandish language used. Or anything. It's very pleasant on this end." Complaints regarding public housing include higher crime rates, police often being called, arguments and fights, and noise in general. Respondents also opposed the development of supportive housing in the neighborhood, whether a group home for mentally ill adults, halfway houses for young people aging out of foster care, or housing for the homeless.

The ultimate insiders in these neighborhoods are the intergenerational households. We visited many homes that contained three generations of the same family. These residents expressed a heightened sense of responsibility for maintaining not only neighborhood stability but also the well-being of their family members. The multi-generational nature of some households is another explanation for why people choose to remain in otherwise unstable neighborhoods.

It is not immediately obvious how residents' distinctions between insiders and outsiders relate to neighborhood stability or inform foreclosure intervention. Yet the fact that the theme of insider/ outsider arose with such frequency when residents were asked about abandoned foreclosed homes suggests that residents do make such a connection.
The insider/outsider duality may in fact suggest why residents choose to remain in unstable neighborhoods: They view them as both good and bad places to live.

Sociologists have long sought to determine why residents remain in disadvantaged neighborhoods (beyond the lure of low rents). Early-20th-century sociologists somewhat optimistically labeled these neighborhoods "zones of transition,"13 suggesting a dynamic process in which residents would move through on their inevitable climb up the economic and social ladder. As the 20th century progressed and many residents remained in this "zone of transition" for multiple generations, Gans suggested that residents were "trapped" by structural forces. ${ }^{14}$ More recently, the Urban Institute began to label low-income neighborhoods, hoping to tap into what causes residents to remain in disadvantaged neighborhoods. ${ }^{15}$

However, explaining why residents remain in unstable neighborhoods is different from understanding how residents function in neighborhoods they themselves see as unstable, dangerous places. The patterns that emerged in our survey sample may indicate how residents cope with instability. When explaining neighborhood conditions, many residents employ social and spatial boundaries, between good and bad places, between "us" and "them," and between insiders and outsiders, perhaps similar to how many urban residents distinguish safe places from unsafe ones. For residents of highly unstable neighborhoods, however, these boundaries are more tightly drawn, encompassing perhaps a street, a section of the street, or sometimes just the dwelling unit itself.

\section{Social Stability and Public Policy}

I believe that the distinctions residents make between insiders and outsiders provides a window into understanding the relationships among household stability, neighborhood stability, and the role of public policy. Household or individual stability is the result of consistency and predictability, which allow household members to thrive. From an individual or family stability perspective, living in highly unsafe and unstable environments makes no sense; the family would be far better off moving to a safe, predictable environment. Yet for complex reasons, many residents stay. Conversely, from a community perspective, residential turnover erodes stability. Many studies show that high residential turnover 
is closely correlated with higher levels of crime and lower quality of life. The community is better off the longer its members stay.

This situation might seem like a paradox: while it is in an individual's best interest to leave an unstable neighborhood, it is in the community's best interest that he or she stays (assuming that the individual is not a source of neighborhood problems). However, the situation is actually a justification for policy intervention to break the familiar vicious cycle: creating safe, stable communities encourages families to stay, and families who stay are critical in ensuring stability and stability. Residents who remain in unstable neighborhoods contribute to neighborhood stability. Insights from residents about how they maintain a sense of stability suggest how residents make staying tolerable and how policy can enhance the tolerability of unstable places.

Residents of unstable neighborhoods construct a sense of safety by dividing their communities both spatially and socially into areas of positively influencing insiders and negatively influencing outsiders. Making spatial distinctions, such as viewing their part of their block as a safe zone and making social distinctions between those seen as committed to neighborhood safety and those who are not, appears to help residents cope with living in unstable communities. This coping mechanism could be enhanced through policy intervention.

Together, these findings suggest that effective neighborhood stabilization in low-income neighborhoods should support foreclosure remediation in several ways. While it is too soon to make recommendations for Boston's program in particular (and I know of no similar studies with which to compare results), I will draw some simple conclusions - while attempting to avoid generalizations.

First, policy needs to support the linkages residents make between social stability and price stability. Policies must do more than promote the creation of desirable dwelling units; they must foster neighborhood environments where people choose to stay. This includes helping residents expand their spatial and social boundaries of whom they consider inside and outside the "safe zone." This may involve simple measures like rethinking the "block party" approach, which may reinforce insular thinking. Instead cities should encourage residents to meet neighbors from a wider radius. At the target block level, placing homeowners in NSP homes may signal to the community that the city believes this is a place worth investing in.

Second, policy needs to recognize that residents in highly distressed neighborhoods see far greater threats to neighborhood stability than home foreclosure: gun violence ranks Number One. Nevertheless, even vacant lots appear to increase Boston residents' sense of unease more than vacant homes do. Boston is fortunate that most residents endorse police and city power. Stabilization policies can enhance governance through augmented police presence, vigilant code enforcement, and priority responsiveness to citizen complaints. All of these actions will increase residents' confidence that the City is committed to supporting distressed communities.

Third, policies need to capitalize on the strength of neighborhood and municipal organizations and promote connections between them. Though some of the residents we interviewed participate in neighborhood organizations, many view local and city institutions as effective. Policy makers might do well to visit these neighborhood organizations, arrange collaborations with them, and solicit residents' ideas about how to confront neighborhood problems. In any event, policy should actively support community governance, encouraging neighborhood organizations to convene meetings and events that embolden residents to broaden their boundaries and regain a sense of control over the larger neighborhood.

\section{Many studies show that high residential turnover is closely correlated with higher levels of crime \\ and lower quality of life. The community is better off the longer its members stay.}

Hopefully, the information presented here might call into question some seemingly untested assertions, such as one made by the Vacant Properties Campaign that, "by all accounts vacant properties are a curse. Just ask anyone who lives next to a drug den, a boarded-up firetrap or a trash filled lot."16 Or the assumption that "the growing crisis in vacant and abandoned properties, communities are increasingly saddled with empty, deteriorating houses that devalue neighboring properties, attract crime, and demoralize neighborhoods." ${ }^{17}$ We talked to people in distressed neighborhoods about abandoned properties near them. While residents 
felt concerned about neighborhood conditions, these concerns often extended far beyond the abandoned property. It might be that neighbors living in less socially distressed neighborhoods would express more concern about foreclosed properties. Our follow-up survey next year will tell us more about how formerly abandoned properties (now renovated and occupied) affect residents' sense of neighborhood stability. We can also compare these reactions to those of residents who live next to the control properties, some likely to remain abandoned, and others possibly rehabilitated through the private market. By comparing residents' reactions before and after the intervention, we hope to gain a fuller understanding of the impact of the foreclosure intervention policy.

Erin Graves is a Policy Analyst at the Federal Reserve Bank of Boston in Community Development

\section{Endnotes}

1 City of Boston, 2010. "Foreclosure Trends, 2010."

2 Boston Redevelopment Authority, 2010. "Census Tract and Block Group Geographies - 2000 \& 2010."

3 Boston Police Department, 2009. "2009 Crime Summary."

4 Mallach, A, 2009, "Stabilizing Communities: A Federal Response to the Secondary Impacts of the Foreclosure Crisis" Washington: Brookings Institution.

5 Kirk, D.S and Laub, J.H, 2010 “Neighborhood Change and Crime in the Modern Metropolis." Crime and Justice 39 (1),441-502.

6 To view the survey, please see Appendix A: Survey Instrument on the NECD webpage: http://www.bostonfed.org/commdev/necd.

7 Please see Appendix B: Methodology, for a detailed description of the methods used to recruit participants.: http://www.bostonfed. org/commdev/necd

8 City of Boston's "2010 Distressed and Abandoned Buildings Report" listed 99 properties as vacant or abandoned in our target neighborhoods.

9 For more resident quotes, see Appendix C: "Resident Views of Abandoned, Foreclosed Homes": http://www.bostonfed.org/ commdev/necd

10 For more resident quotes, see Appendix D: “Other Threats to Neighborhood Stability": http://www.bostonfed.org/commdev/ necd

11 For more resident quotes please see Appendix E: "The Role of City and Community Institutions in Neighborhood Stability": http:// www.bostonfed.org/commdev/necd

12 For more resident quotes, please see Appendix F: "Stability and Sense of Community": http://www.bostonfed.org/commdev/necd

13 Burgess,E.W., 1929. "Urban Areas" in, T. V. Smith and Leonard D. White (eds.), Chicago: An Experiment in Social Research (Chicago, Illinois: University of Chicago Press, 1929), 114-115.

14 Gans H-J., 1962, "Urbanism and Suburbanism as Ways of Life: A Reevaluation of 'Definitions'”' In: Rose A-M. (ed.), Human Behavior and Social Processes, Boston, Houghton Mifflin, 625-648.
15 Coulton, C., Theodos, B., \& Turner, M.A., 2009. “Family mobility and neighborhood change: New evidence and implications for community initiatives." Washington, DC: Urban Institute.

16 National Vacant Properties Campaign, 2005. "Vacant Properties: The True Costs to Communities" National Vacant Properties Campaign: Washington DC.

17 Griffin, M. 2010. "The Community Reinvestment Act and NSP: A Banker's Perspective" REO and Vacant Properties: Strategies for Neighborhood Stabilization. Washington D.C.: Federal Reserve Bank of Boston and Cleveland and the Federal Reserve Board, pp. 151-153. 
What Do the Neighbors Think? Assessing the Community Impact of Neighborhood Stabilization Efforts Appendix A: Survey Instrument

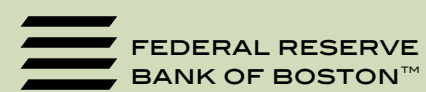

\section{Sense of Community in High Foreclosure Neighborhoods}

The Federal Reserve Bank of Boston

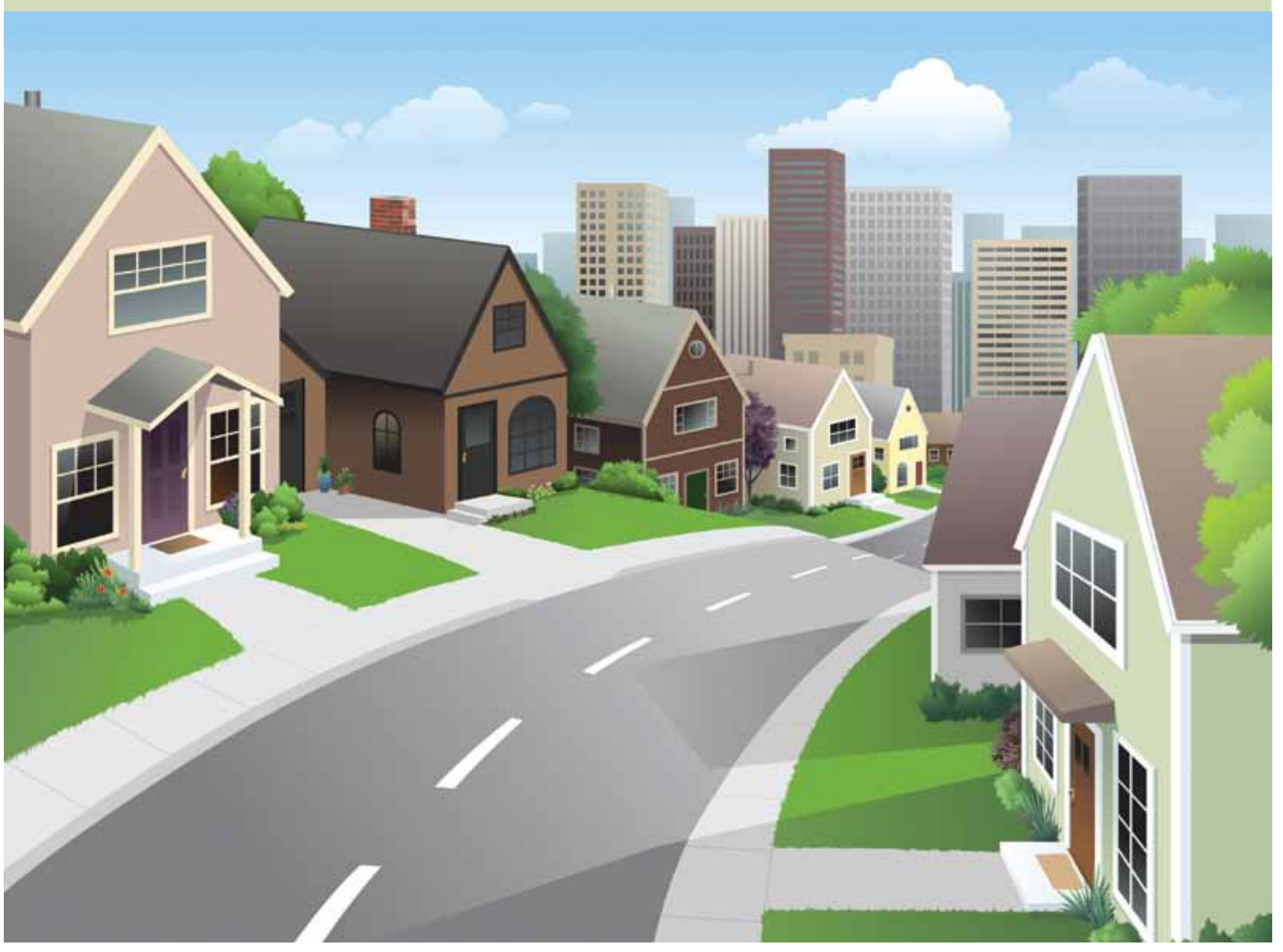


This survey should take approximately 5 to 10 minutes to complete.

All responses will be kept confidential.

Thank you for your participation.

\section{For questions 1 and 2 please write in your response or check the appropriate box.}

For this section, please consider your neighbors to be the people whose bomes you can see from your front door and your

block to be the houses you can see from your front door.

For questions 3 through 7 please read the following statements and indicate whether you agree or disagree by checking the appropriate box.
For questions 8 through 12 please read the following questions and check the box that corresponds with your answer.
1. How long have you lived at your current address?

_ years months

2. What are your current living arrangements? $\square$ Own

$\square$ Rent

$\square$ Live with parents/family/friends

$\square$ Other
3. Very few of my neighbors know me.

4. I have almost no influence over what my block is like.

5. I can recognize most of the people who live on my block.

6. My neighbors and I want the same things from the block.

7. If there is a problem on my block people who live here can get it solved. $\begin{array}{cccc}\begin{array}{c}\text { Strongly } \\ \text { Agree }\end{array} \text { Agree } & \text { Undecided } & \text { Disagree } & \text { Strongly } \\ \text { Disagree }\end{array}$
8. In general, would you say that people on your block watch after each other and help out when they can, or do they pretty much go their own way?

$\begin{array}{ccccc}\begin{array}{c}\text { Always go } \\ \text { own way }\end{array} & \begin{array}{c}\text { Mostly go } \\ \text { own way }\end{array} & \begin{array}{c}\text { A little of } \\ \text { both }\end{array} & \begin{array}{c}\text { Sometimes } \\ \text { watch after }\end{array} & \begin{array}{c}\text { Always } \\ \text { watch after }\end{array} \\ \square & \square & \square & \square & \square\end{array}$

9. Would you say that it is very important, somewhat important or not important to you to feel a sense of community with the people on your block?

$\begin{array}{ccccc}\begin{array}{c}\text { Not } \\ \text { Important }\end{array} & \begin{array}{c}\text { Of Little } \\ \text { Importance }\end{array} & \text { Undecided } & \begin{array}{c}\text { Moderately } \\ \text { Important }\end{array} & \begin{array}{c}\text { Very } \\ \text { Important }\end{array} \\ \square & \square & \square & \square & \square\end{array}$

10. Some people say they feel like they have a sense of community with the people on their block; others don't feel that way. With others on your block, would you say you feel like you have very little sense of community, or very strong sense of community, or something in between? 
What Do the Neighbors Think? Assessing the Community Impact of Neighborhood Stabilization Efforts

$\begin{array}{lcccc}\text { 12. Overall, how would you rate your } & \begin{array}{c}\text { Very } \\ \text { Pleasant }\end{array} & \begin{array}{c}\text { Somewhat } \\ \text { Pleasant }\end{array} & \begin{array}{c}\text { Not Very } \\ \text { Pleasant }\end{array} & \begin{array}{c}\text { Not at all } \\ \text { Pleasant }\end{array} \\ \text { block as a place to walk? } & \square & \square & \square & \square\end{array}$

13. How safe from crime do you

\begin{tabular}{|c|c|c|c|}
\hline $\begin{array}{l}\text { Extremely } \\
\text { Safe }\end{array}$ & Quite Safe & $\begin{array}{l}\text { Slightly } \\
\text { Safe }\end{array}$ & $\begin{array}{l}\text { Not at all } \\
\text { Safe }\end{array}$ \\
\hline
\end{tabular}

The following questions regard the building at

123 Main St.

City records indicate that this building has been foreclosed on. Please read each question and check the appropriate box or write in your response.
14. Has the owner or manager of this $\quad \square$ Yes property contacted you regarding $\square \square$ No the property or its condition?

15. Have you contacted anyone about $\square$ Yes the property or its condition?

$\square$ No

If NO please Go to Question 19

16. Why did you contact someone about the property?

17. Who did you contact? $\square$ Owner

$\square$ Police

$\square$ Occupant
$\square$ Building Manager
$\square$ City

$\square$ Neighborhood Organization

$\square$ Mayor's Hotline

$\square$ Other

18. Were you satisfied by the response? $\square$ Yes
We would like to know if you participate in any neighborhood groups or activities.
19. In the past 12 months, have you participated in the following activities:

a. Attended a neighborhood or block organization meeting?

$\square$ Yes

$\square$ No

If Yes, what organization?

b. Been part of a group that got together to try to change something in your neighborhood or community?

$$
\square \text { Yes }
$$$$
\square \text { No }
$$

If Yes, what group?

c. Been a part of another type of local group or organization? Such as a place of worship or community center.

$\square$ Yes

$\square$ No

If Yes, what organization? 
What Do the Neighbors Think? Assessing the Community Impact of Neighborhood Stabilization Efforts Appendix A: Survey Instrument

We would like to collect some basic demographic information. Please read each question and check the appropriate box or write in your response.
20. What is your gender? $\square$ Male

$$
\square \text { Female }
$$

21. What is your age? Years

22. What is your relationship status?
$\square$ Single
$\square$ Living with Partner
$\square$ In a relashionship
$\square$ Married
$\square$ Divorced or Seperated
$\square$ Widowed

23. Do any children live with you?

$$
\begin{aligned}
& \square \text { Yes } \\
& \square \text { No } \\
& \text { If Yes, how many? }
\end{aligned}
$$

24. Which best describes your current employment situation?
$\square$ Full-time (more than 30 hours)
$\square$ Full-time student
$\square$ Part-time/casual job
$\square$ Retired
$\square$ Home maker
$\square$ Not currently employed

25. What is your race?
$\square$ White
$\square$ Black, African American
$\square$ Asian
$\square$ Other

26. Are you Hispanic or Latino, or $\quad \square$ Yes Spanish origin?

27. What is your ethnicity?

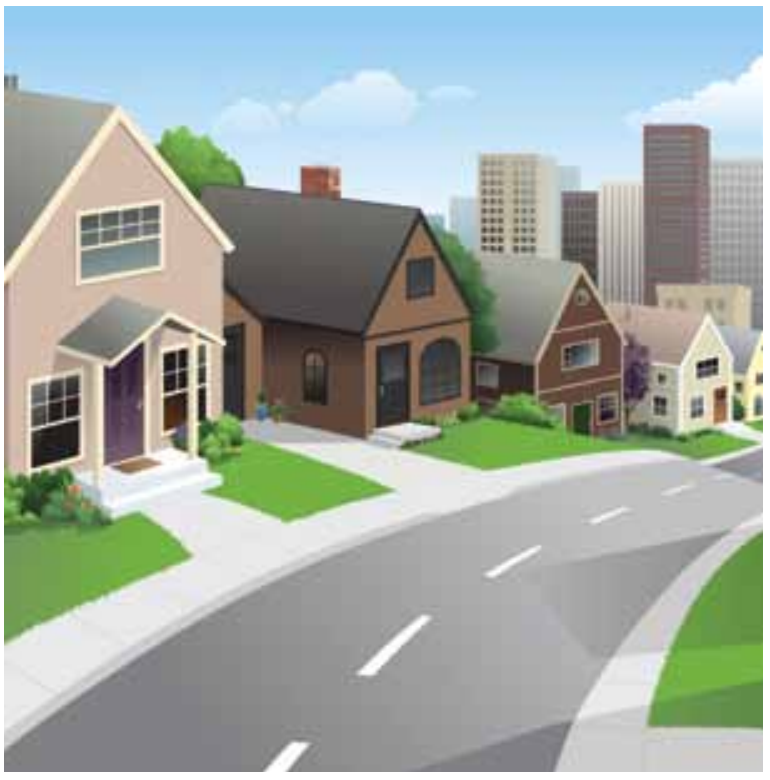

In the space below, please share with us any other comments on how you feel about your neighborhood. 


\section{What Do the Neighbors Think?}

\section{Assessing the Community Impact of Neighborhood Stabilization Efforts}

\section{Appendix B: Methodology}

We decided that the intervention would have the greatest impact on those who live closest to the abandoned buildings; therefore, we included in our universe all residents of buildings that directly abut an abandoned property, all buildings that were one house away from the abandoned house and all buildings directly across the street from these houses. The figure below illustrates a typical block and the houses that would have been considered in our sample. In certain instances we included houses that did not fit these rules. This occurred when upon visiting the block we noted that a house outside of this area had a very clear view of the house, thus suggesting that the residents of the building would be aware of and potentially influenced by the abandoned building.

Upon identifying these buildings we visited every street and attempted to conduct an in-person interview at every unit in the buildings that were in our universe. We rang the door-bell or knocked on the door. If someone answered the door, we introduced ourselves and explained the survey. If a resident was willing to participate, we administered the survey in the entryway or in some instances inside the respondent's home. We administered the survey to every resident over 18 , who was present and willing to participate in the survey. All participants were given a money order for $\$ 20$. In a few instances, residents indicated that they were not interested in participating, in which case we removed the unit from our list. If no one answered the door, we would leave a flyer with our phone number telling the resident that if they were eligible to participate in a short survey and we would pay them $\$ 20$ for participating. We visited neighborhoods and conducted surveys between the hours of $2 \mathrm{pm}$ and $8 \mathrm{pm}$ on weekdays and Sundays in the months of June and July.

Given the fact that many residents either did not answer their doors or were not home when we visited their homes, we decided it was important to attempt to contact these residents by other means. We therefore decided to do a mailing in addition to the door-to-door surveys. In order to personalize the mailing we used the Boston Resident List, which was obtained from the Boston Elections Department. The list contains the names and addresses of Boston residents and is collected annually. The list is not comprehensive. We compared the names of the people we interviewed in person to the list and found that roughly 20 to 30 percent of the respondents were not included on the list. In most cases the people who were not on the list reported moving within the last year. Though there were some long time residents who were not on the list. While the list was imperfect we felt that a personalized letter and mailing would be more likely to produce a response than an anonymous mailing.

Therefore we used the Resident List to generate a mailing list with every resident of the buildings that were in our universe. We removed from the mailing list any resident who we had interviewed in person and all of the residents of the unit that the respondent lived in. In addition, we removed from the list the residents of any unit where we had been told that they were not interested in participating. The list contained 410 residents of addresses that were contained within our buildings of interest.

We followed the Dillman Taylor Design Method (2009): after our initial mailing we mailed a reminder postcard to all unresponsive households. Finally, we mailed a reminder letter with a replacement survey to all residents of non-responding units. If the mailed surveys were returned marked "vacant," we removed this household from our list, leaving us with an estimated total of 256 households, 123 of which responded to our survey (response rate $48 \%$ ). 


\section{What Do the Neighbors Think?}

\section{Assessing the Community Impact of Neighborhood Stabilization Efforts}

\section{Appendix C: Resident Quotes about Abandoned, Foreclosed Homes}

- Many residents were not aware the home had been foreclosed on.

- $\quad$ One young women responded, "I didn't even know it was closed until you told me."

- A male renter commented, "Wow, it's a foreclosure. Nobody knows about it. "

- For those who did know of the foreclosure, several explained the foreclosure as an outcome of an individual problem rather than a sign of a community issue.

- An older woman living in her elderly mother's home recounted how a "Woman, husband and mother owned [the foreclosed home] for over 40 years, and the granddaughter manipulated it out of her hands and she lost it, she was using it for collateral on projects elsewhere."

- Another middle aged woman recalled that, "The homeowner of [the foreclosed property] was a very pleasant person. Always greets his neighbors. I think it sad when people lose their homes."

- A male owner detailed how the owners got "swindled" by the banks. In each of these resident narratives, their focus is on the individual circumstances of the former owners.

- We rarely heard reports of crime in foreclosed homes.

- One older female owner attested, "No one goes in there [foreclosed house]. If someone went in there the neighbors would call."

- Another older female owner responded similarly, "I'm watchful and would report anything." Moreover, she reported that the house didn't concern her very much. "[It] hasn't affected the block" because "It's not that run down."

- Other residents recalled activity in the home, and their response to it.

- One middle aged female renter told us that one day she several children came running out of the foreclosed home. She called the police and a neighborhood group. Soon thereafter, "They came and boarded it up."

- A retired male renter living near that same house recalled how at one point, "There was a lot of trash, doors and windows were open. " He responded by contacting several agencies, including Inspectional services, City Hall and the Mayor's Office.

- Many residents viewed abandoned lots as an equal, if not greater, threat to neighborhood stability.

- One middle aged female renter referenced the vacant lot next door to her (the foreclosed home 
abutted her on the other side). She commented of that vacant lot, "there goes your sense of community."

- A female middle-aged renter wrote that, "There is an empty lot beside my apartment, which needs to be kept up. There are bushes over there and the neighbors throw trash over there and I wish the city would do something about it."

- A female renter noted that, "We have vacant lots. They [the city of Boston] need to put something there instead of just trees and weeds."

- Another female renter suggested, "If the city of Boston were to maintain its vacant lots and hold property owners responsible for their abandoned lots and units our neighborhood would prosper much faster. "

- A female owner said that she and "a few others, who think [vacant lots] are very distracting. It is going to cause people to hang out there, throw trash."

These comments, in contrast to those made on the foreclosed homes, suggest that residents perceive abandoned lots to be a threat to community stability. Residents associate empty lots to loss of sense of community and lack of community neighborhood prosperity. 
What Do the Neighbors Think?

Assessing the Community Impact of Neighborhood Stabilization Efforts

\section{Appendix D: Resident Quotes about Other Threats to Neighborhood Stability}

- Residents recounted illegal and anti-social activities in general terms

- One woman who noted, “There are major crimes on the cross streets. We try to get people to notice things- to pay attention.”

- Another woman recounted how, "We still deal with a lot of violence, drug addicts, and home or auto theft.”

- A young man reported that, “Two months ago someone broke into two cars and broke the window.”

- Another young man reported that he saw, "prevalent drug dealing and prostitution that occurs around the corner.”

- Another male renter detailed how he sees, "Drug addicts and deals on steps of homes or corners; gangs/robbery/assaults.”

- Many residents also recalled in detail specific incidences of gun violence.

- As one female homeowner on one street recounted, "Believe it or not, I have literally witnessed three people lying in the street after being shot. I don't know if you'll recall in the news, Halloween they shot someone. Another holiday they shot, it was a teenage boy.”

- A female homeowner on another street spoke of how "Somebody just got shot [one street over] last week. They did a big community meeting, they did a big block party trying to straighten the air up. A massive email went up from the police department.”

- Another female renter recalled how, “There was a shooting. “

- A female homeowner told us how, "The other night there were five shots right here.”

- A male renter related that "Wish they would stop the gunfire. A little boy was shot."

- A Female Latino renter on that same street related an episode, "Like we had two shootings, actually, like in my apartment. There were bullets coming straight into my apartment last summer, twice. And it was all due to the people who lived upstairs who eventually got evicted. That created like a really sense of insecurity on the street. They would keep the people on the porch and they would be in front of the house. And it was bad. It is better now, it is a lot quieter with them gone, actually. The people on the street, a lot of people are older people, people who work, um, have families. Those people, just I don't know, just didn’t fit in at all on the street.” 
- A woman living with family commented that, "There was a gun shot behind the house. A kid threw his gun and it went off. The cops came by afterwards w/in minutes because of a new police program shot spotter."

- A male renter speculated, "If we got rid of the guns it would be safe." 
What Do the Neighbors Think?

Assessing the Community Impact of Neighborhood Stabilization Efforts

\section{Appendix E: Resident Quotes about the Role of City and Community Institutions} in Neighborhood Stability

- Residents offered many comments regarding the performance of police and other institutional actors charged with maintaining social stability.

- One young adult male renter noted that, "I feel like my neighborhood could be better if there was more cops in it."

- Another middle aged female homeowner argued, "We need more patrols. More police presence."

- Another elderly female homeowner explained, "There needs to be more police visibility. I hardly ever see police coming through or driving through the street to make their presence known."

- Additionally, many view local community organizations as effective in confronting some neighborhood problems and instrumental in bridging community concerns to city level actors.

- As one older female renter recounted, "Over the years there have been incidences [of crime] but because of the neighborhood association and the community watches [in neighboring developments] it's been controlled. “

- Another elderly female home owner related that her daughter served as the, "Neighborhood Association president. It takes time but can be done."

- An older male homeowner detailed how a neighbor living on an adjoining street was the leader of a neighborhood organization. "So he can give you all kinds of [advice]. So we are very active in the organization, and everybody is quite participating. If anything happens in this community, so there's this issue we try to solve."

- Other residents believed that neighborhood participation were necessary to bring about positive change and that residents needed to be more engaged.

- As long term homeowner argued that people can solve community problems, "if they have the right resources."

- Another renter wrote "I feel there should be more community participation, and a way to gather the residents together to get more involved with their community/block." 
- Another resident believed that "my neighborhood should have better organizations and we all should share our opinions. Also the government should fix things around here."

- Many residents see bridging between local and municipal organizations as crucial in promoting neighborhood stability.

- One female homeowner "belongs to the neighborhood association which has monthly meetings and get a lot done, for example, they got stop signs. There is a community officer who reports to the group on the monthly crimes. Encourages everyone to call 911 if they see anything. "

- Another long-time female owner noted that "The neighborhood has changed a lot of the people who have moved in are younger people. So there are a lot of parties w/ noise late at night. But [the neighborhood association] takes care of it. First we talk to them, if they don't respond we call the police to let them know that we tolerate this."

- Some residents did express a sense of institutional abandonment and alienation.

- One young woman believed that her communities' inability to effectively confront instability was "because the state's an ass."

- One homeowner expressed frustration with both government and banks and their role in the foreclosure issue. " The city/government is reactive rather than proactive. They wait until they're in foreclosure. Banks are the same. No one is helping people keep their homes. "

- Where it comes to foreclosure we haven't had much luck, but when it comes to sanitation...we have garbage pick-up 2 days a week."

- Another person noted, "I wish banks and other lenders could work with owners to avoid these problems."

- As detailed above, one man recounted how the owners of the foreclosed home got "swindled" by the banks." 
What Do the Neighbors Think?

Assessing the Community Impact of Neighborhood Stabilization Efforts

\section{Appendix F: Resident Quotes about Stability and Sense of Community}

- Residents spoke of their neighborhoods in negative terms, they related positive views as well.

- I coded 47 statements relating positive sentiments about the neighborhood as positive ones and about 49 as negative ones.

- Sometimes the negative and positive perspective would be contained in the same sentiment. For example, a young male resident noted, "I love the neighborhood with the exception of prevalent drug dealing and prostitution that occurs around the corner."

- A female renter with 3 young children noted that her neighborhood was "very pleasant -- until about 7 o'clock."

- A young single man who lived with his family members reported that in his neighborhood, "Sometimes it's quiet. Sometimes it's not quiet."

- A middle-aged female owner recounted that, "I would say quite safe although (laughing) given some of the news reports what is striking to me is for some reason there's a lot of stuff that happens on this street."

- First, in reviewing residents' comments, it became clear that many residents draw careful distinctions between well-intentioned insiders and poorly behaved outsiders.

- One woman recounted, "On occasion, there is violence..." But she was also careful to add, "...on the first street over."

- Another resident vouched for her side of the street commenting, "We haven't had any trouble, as you say, where we can see. The other side is a different story."

- Another female homeowner noted that while her street was safe, "There are a couple of streets that have bad residents that flow into our street."

- Another female renter phrased it more directly, "I find that lots of things happening in the area are done by outsiders."

- Another female renter reported that while no violence occurred on her street, "A couple of streets over I heard about gang violence, shootings. "

- A female homeowner vouched for her immediate neighbors, saying that the gun violence she witnessed was, "Never people, in this-- who live on these blocks. Or, you know, so it's kind of 
odd."

- Another male renter told us about killings that occurred, "further down [the street]."

- A male renter literally distanced himself from instability, recounting, "If there is ever any problem it is always at that end."

- Homeowners and renters alike describe homeowners as committed, responsible and admirable community members and compare this to the behavior of renters.

- For example, a older male renter maintained a positive view of his block explaining, "there's homeowners and they seem to keep it up."

- Other people suggested that homeowners have a particular responsibility to maintain order. As one older female renter stated, "Resident owners should not let groups of people standing in front of their homes smoking, drinking or even being loud with conversation."

- A young female renter attributed the low level of crime on her street to the presence of homeowners, "I haven't heard any gun shots, which is a plus. [This street has] mainly homeowners and they are older."

- One middle aged male homeowner attributed instability to tenants, arguing, "A lot of people around here now are tenants, not homeowners ....The tenants are residents, but you know what I mean, they change all the time."

- An older homeowner described the abandonded forclosed home this way, "The abandoned home is the eyesore of the street. In the 27 years I have been back here, the house and tenants have been less than good. [I have] often suspected drug activity. "

- A middle aged male renter (57) explained his feelings of marginalization because of his housing tenure, "It is difficult for renters to feel a sense of ownership and power in a neighborhood like this. Renters are temporary. “

- Resident repeatedly cited long-term residents as a source of stability without direct reference to their ownership status.

- As one older female homeowner explained, "I've lived in this neighborhood for the past 30+ years without any major incidents. Neighbors always offered help."

- Another middle aged man recounted, "Our family has lived in the house since 1974 and everybody knows me and I know them."

- A young man living with family commented on his neighborhood, "It's nice... a lot of old people live on this street." 
- A middle aged female renter linked the high quality of the neighborhood to the presence of long-term residents. She recalled that when she first moved to the neighborhood she met a long-term resident and "she was like, really nice "oh, its really nice. we've lived here for I don't know how many years." The guy next door had been an owner for like ten years... Because like the ones that are pretty much here, are like older, been here for a long time. "

- A middle aged woman who lives with her family related a positive view of her neighborhood and explained, "The same people have lived on this street for over 30-40 years... the street is changing."

- Residents do, however, make class distinctions based on income.

- As one older male renter explained, “And I don't like to generalize and category people, but the closer you get to the public housing, and to the, yeah, the closer you get to the end with public housing it's always a problem at that end. Where the private homes are you never see any police come down here, never any fights any argument, you know none of that outlandish language used. Or anything. It's very pleasant on this end." Another older female homeowner expressed a similar view of residents receiving housing subsidies, "This neighborhood is very noisy all times of the day. Most of this can be attributed to the apartment building on the street and surrounding streets. Most of the tenants are young, on assistance and somewhat transient. I do not believe landlords care. " Another older female homeowner attributed the violence occurring on her street to people "running from these [housing ] projects over this way." And a third female homeowner detailed how the subsidized housing residents, "are not grateful. Government, tax dollars assisting them with the rent. The increase in crime has occurred since they moved in."

In addition to distinctions residents make by economic class, residents also opposed the development of supportive housing in the neighborhood. One middle aged female homeowner complained that "Recently a 'mental house' was built down the street." Another older female homeowner wrote that she hoped that the abandoned, foreclosed home in question would be rehabilitated and that she "would love to see respectful law-abiding families to move in not rooming house or halfway house." Another homeowner recounted how she initially objected to the City's plans to convert the abandoned, foreclosed home into a " become a transition home for Little Wanderers [kids aging out of foster care]. " However, after the developer had presented the plans before the 
neighborhood council, she changed her mind and decided, "It will be good if it's done right. New folks, will help them acclimate to life beyond foster care. " Not every resident objected to the idea that the treatment properties might be converted into supportive housing. As one resident suggested, "I guess they should fix up the building for homeless people. " It may not come as a surprise that this woman was a renter and not a homeowner and therefore probably did not see herself as having a financial stake in the neighborhood.

The ultimate insiders in these neighborhoods are the intergenerational households. We visited many three-family homes that contained three generations of the same family. These residents expressed not only a heightened sense of responsibility for maintaining neighborhood stability but also for the well being of their family members. For example, one resident we interviewed told us, "My granddaughter lives on the third floor." Then her grand daughter arrived home during interview and hovered protectively until we were finished. Another elderly woman let us in to the building and her daughter opened the door to her $1^{\text {st }}$ floor apartment, "what going on mom?" The mother explains that "these girls are doing a survey." The daughter insisted that we conduct the interview in her unit. Once inside, the daughter asked her mother again if she is interested in doing the survey. The mother insisted that she wanted to participate. The daughter again reiterated that the mother did not have to do the survey and remained in the room until we finished. The presence of multi-family, multi-generational households is yet another explanation for why people choose to remain in otherwise unstable neighborhoods. 